\title{
Effect of 2,4-D on leafy spurge (Euphorbia esula) viable seed production ${ }^{1}$
}

\author{
JAMAL S. AL-HENAID, MARK A. FERRELL, and STEPHEN D. MILLER \\ The authors are a former grad. student (now Postdoc. Res. Assoc., Everglades Res. \& Ext. Cent., Belle Glade, FL \\ 33430); Ext. Pestic. Coord.; and Prof. Dep. Plant Soil Insect Sci., Univ. Wyo., Laramie, WY 82071, respectively.
}

\begin{abstract}
:
Leafy spurge viable seed production and germination were reduced by 2,4-D applied during flower development and seed formation, in the field. Viable seed production was reduced when 2,4-D was applied at all growth stages after the start of flower bud development. The number of viable seed from untreated plants was 173 , while, the number of viable seed from plants treated $0,7,14,21,28$, or 35 days after the start of flower bud development was $<1,4,7,31,53$, and 62 ; respectively. Leafy spurge seed germination was higher in gibberellic acid than in water for seed collected from untreated plants and from plants treated with 2,4-D 7, 14, and 21 days after bud initiation. This research shows that 2,4-D must be applied prior to flower bud development to prevent seed production.
\end{abstract}

\section{Nomenclature:}

2,4-D (2,4-dichlorophenoxy)acetic acid; gibberellic acid, 2,4a,7trihydroxy-1-methyl-8-methylenegibb-3-ene-1,10-carboxylic acid $1 \rightarrow 4$ lactone; leafy spurge, Euphorbia esula L. $\#^{2}$ EPHES.

\section{Additional index words:}

Gibberellic acid, germination.

\footnotetext{
${ }^{1}$ Received for publication Mar. 3, 1992 and inrevised form Sept. 28, 1992. Published with the approval of the Director, Wyoming Agric. Exp. Stn. as J. Art. No. 1582.

${ }^{2}$ Letters following this \# symbol are a WSSA-approved computer code from Composite List of Weeds, Revised 1989. Available from WSSA, 309 W.Clark St., Champaign, IL 61820.
} 


\section{Introduction}

Leafy spurge is a creeping, tenacious, perennial dicot that is classified as a noxious weed in Wyoming according to the Wyoming Board of Agriculture and Wyoming Weed and Pest Council (7). It is a major weed problem because it spreads rapidly and is difficult to control. Leafy spurge infests an estimated 1.1 million ha in North America (5). There are over 19,000 ha infested in Wyoming and it occurs in every county (7).

Leafy spurge spreads by seed and underground roots containing numerous crown and root buds. Depending on environmental conditions, flowering shoots may produce from 10 to 50 capsules per shoot. In Wyoming shoots from undisturbed plants can appear as early as the end of March or early April and flowers emerge from mid-May to mid-June depending on elevation and climatic conditions.

Wicks and Derscheid (10) found leafy spurge seed changes color from yellow to yellow with brown tips, to brown ends with a narrow yellow band, to brown with an orange band, and to a reddish-brown seed, followed in order by brown, gray-brown, gray, and mottled. Only the last four stages produce viable seed. Mowing leafy spurge to prevent viable seed production must be done before seeds turn brown which occurs 10 to 13 days after fertilization depending upon seasonal conditions (10). As the ovary ripens, several layers of columnar cells in the seed capsule dry, pulling the edges of the locule together, and develop tension on the capsule until it explodes (2). Leafy spurge seed may be propelled as far as $4.5 \mathrm{~m}$ from the parent plant $(2,4)$. An average leafy spurge plant, grown in competition with native grass in Saskatchewan, Canada, has produced 252 seeds (9). The greatest leafy spurge seed production reported has been $3800 \mathrm{~kg} / \mathrm{ha}^{-1}$. However, average production of leafy spurge is about 2500 seeds per $\mathrm{m}^{2}$, with seed production varying from 790 to 8020 seeds per $\mathrm{m}^{2}$ (3).

Leafy spurge requires repeated applications of herbicides for effective control. Common herbicides to control leafy spurge include 2,4-D, dicamba (3,6-dichloro2methoxybenzoic acid), and picloram (4-amino3,5,6-trichloro-2-pyridinecarboxylic acid). These herbicides are selective for broadleaf weeds and do not harm grasses when applied at proper rates (1).

The objective of this study was to evaluate leafy spurge viable seed production as influenced by 2,4-D applied at weekly intervals beginning with flower bud development and continuing through seed formation. No previous work on this subject was reported in the literature.

\section{Materials and methods}

The experiment was conducted near Lander (elevation $1676 \mathrm{~m}$ ) in 1985 and in Cheyenne, WY (elevation $1859 \mathrm{~m}$ ) in 1990. The soil at Lander was Thermopolis loamy, mixed, calcareous, frigid, shallow Ustic Torriorthent with $\mathrm{pH} 8.0$ and $1.9 \%$ organic matter. The soil at Cheyenne was an Albinas loamy, mixed mesic, pachic argiustoll with $\mathrm{pH}$ 7.6 and $2.1 \%$ organic matter. The average annual precipitation was 33 and $41 \mathrm{~cm}$; the 
mean annual soil temperature was 8 and $10 \mathrm{C}$; and average growing season 110 and 149 days at the Lander and Cheyenne sites, respectively.

Healthy, vigorously growing leafy spurge infestations were selected for the study at both locations. 2,4-D dimethyl amine at $2.24 \mathrm{~kg}$ ae/ $\mathrm{ha}^{-1}$ was applied in water with a $\mathrm{CO}_{2}$ pressurized, six-nozzle, knapsack sprayer, delivering $374 \mathrm{~L} / \mathrm{ha}^{-1}$ in 1985 and $180 \mathrm{~L}^{-\mathrm{ha}^{-1}}$ in 1990 at $275 \mathrm{kPa}$. The experiment was a completely random design with treatments repeated three times and experimental units 2.75 by $6.1 \mathrm{~m}$. Treatments of 2,4-D were applied initially when most of the leafy spurge was forming flower buds on June 7, 1985 and May 25, 1990. A second application was made 7 days later when the leafy spurge was flowering. The third application was made 14 days after the initial application, during seed development. The fourth application was made at 21 days when the leafy spurge seed was mostly white in color and soft. The fifth application was made at 28 days when seed was mostly brown in color and still soft. The sixth and last application was made at 35 days when seed was fully developed and gray in color. The seed had not dehisced at this time. In addition, the experiment included an untreated check.

Leafy spurge seed was collected as it dehisced in fine mesh, white, nylon netting which was tied with nylon string around the flowering shoots. Netting was applied as soon as the 2,4-D had dried. Netting was also tied to the untreated check at this time. Seed was collected from 30 randomly selected plants in each of the treated and untreated areas on July 26, 1985 at the Lander site and on July 27, 1990 at the Cheyenne site.

Leafy spurge seed production per plant was determined by averaging the number of seeds collected from each of 30 plants within the same treatment. Percent seed germination was determined by imbibing three lots of 50 seed from each treatment with distilled water or $1000 \mathrm{ppm}$ solution of gibberellic acid $\left(\mathrm{GA}_{3}\right)^{3}$. For a standard measurement, a seed with a $10-\mathrm{mm}$ long radical was considered germinated and was removed from the germination box. Seed was germinated in transparent plastic boxes 13.5 by 13 by $3.5 \mathrm{~cm}$ and placed in an incubator. The average day and night temperatures for germination were $25 \mathrm{C}$ and $15 \mathrm{C}$, respectively. These temperatures were chosen based on research on leafy spurge seed germination as influenced by temperature by Gamal S. Heneidi as reported in his dissertation (6). From this research it was found that the optimum day and night temperature ranges for optimum germination of leafy spurge seed were 24.6 to $30.4 \mathrm{C}$ for day and 7.0 to $25.8 \mathrm{C}$ for night temperatures. Germination tests were performed in the dark. Percent viable seed was determined by a standard tetrazolium chloride $(\mathrm{TZ})^{3}$ test on three lots of 100 seed from each treatment (8). The criterion used to determine seed viability was the color of the embryo after exposure to TZ. A pink embryo indicated a viable seed. Viable seed per plant was calculated from the total seed per plant and percent viable seed.

A completely randomized design with three replications was used in both studies. There was no interaction between years, therefore a combined analysis was run over the two sites. Means were separated with Fisher's Protected Least Significant Difference (LSD) at the $5 \%$ level of significance.

\footnotetext{
${ }^{3}$ Abbreviations: $\mathrm{GA}_{3}$, gibberellic acid; TZ, tetrazloium chloride.
} 


\section{Results and discussion}

The closer 2,4-D was applied to the start of flower bud development the more leafy spurge seed production was reduced (Table 1). There was less than one seed produced per plant when 2,4-D was applied 0 days after the start of flower bud development compared with 201 seed produced by an untreated plant. Total seed production ranged from 9 to 78 for plants treated 7 to 35 days after flower bud development, respectively.

Table 1. Effect of $2.2 \mathrm{~kg} \mathrm{ha}^{-1}$ 2,4-D amine at various application times on leafy spurge seed production, viability, and germination averaged over years and locations.

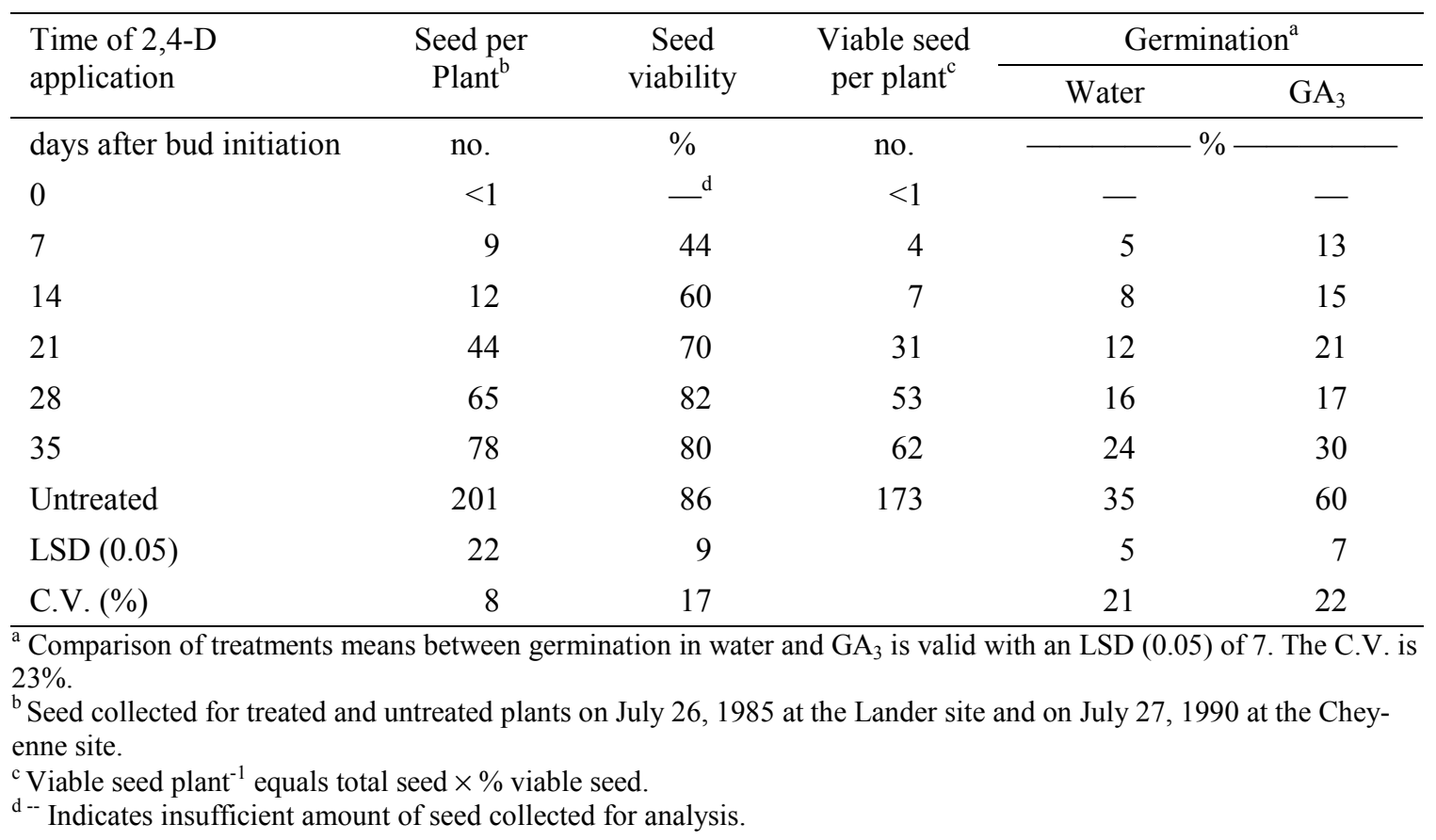

Seed viability was also influenced by 2,4-D applied at various flowering stages. Viable seed production was reduced to less than one per plant when 2,4-D was applied at the start of flower bud development, compared with 173 viable seeds for untreated plants (Table 1). Viable seed production ranged from 4 to 62 for plants treated 7 to 35 days after the start of flower bud development, respectively. Of the total seed produced only $44 \%$ were viable when treated 7 days after the start of flower bud development compared with $86 \%$ viable seed for untreated plants. Insufficient amounts of seed were collected for analysis for the treatment at 0 days after the start of flower bud development due to lack of seed production from plants treated 0 days after the start of bud development. However, this does not necessarily mean that any seed produced after treating with 2,4-D at this stage will not be viable.

Insufficient amounts of seed were collected for analysis of percent germination due to lack of seed production from plants treated 0 days after the start of flower bud development (Table 1). Leafy spurge seed germination was higher in $\mathrm{GA}_{3}$, than in water for seed 
collected from untreated plants and from plants treated with 2,4-D 7, 14, and 21 days after bud initiation. Only 5 and $13 \%$ of the seed were collected 7 days after the start of flower bud development respectively, compared with 35 and $60 \%$ for seed from untreated plants (Table 1). Seed germination ranged from a low of $5 \%$ in water to a high of $60 \%$ when germinated in $\mathrm{GA}_{3}$.

One viable seed has the potential to grow into a plant capable of producing more than 200 seed of which $86 \%$ may be viable, thereby resulting in the reestablishment and spread of leafy spurge. Applications of 2,4-D as early as the start of flower bud development may not completely prevent viable seed production. To prevent flowering and seed production 2,4-D must be applied before the start of flower bud development. However, if early application of 2,4-D was not accomplished viable seed production may still be reduced to almost nil when applied at the start of flower bud development and reduced to less than one-third that produced by an untreated plant by spraying as late as 35 days after

the start of flower bud development. Even though 2,4-D applied 35 days after the start of flower bud development would not prevent seed production and reestablishment of leafy spurge it would assist in decreasing the amount of viable seed in the soil seedbank, thus diminishing the potential for future infestation from seed.

\section{Literature cited}

1. Alley, H. P. and C. G. Messersmith. 1985. Chemical control of leafy spurge. p. 65-78 in A. K. Watson, ed. Leafy spurge. Weed Sci. Soc. Am., 309 W. Clark St., Champaign, IL 61820. p.104

2. Bakke, A. L. 1936. Leafy spurge, Euphorbia esula L. Iowa Agric. Exp. Stn. Res. Bull. 198:209-246.

3. Best, K. F., G. G. Bowes, A. G. Thomas, and M. G. Maw. 1980. The biology of Canadian weeds. 39. Euphorbia esula L. Can. J. Plant Sci. 60:651-663.

4. Derscheid, L. A., K. E. Wallace, and R. L. Nash. 1960. Leafy spurge control with cultivation, cropping and chemicals. Weeds 8:115-127.

5. Dunn, P. H. 1979. The distribution of leafy spurge in North America (Euphorbia esula) and other weedy Euphorbia spp. in the United States. Weed Sci. 27:509-516.

6. Heneidi, G. S. 1987. Leafy spurge control, seed viability and germination. Ph.D. dissertation, Dep. Plant Soil Insect Sci., Univ. Wyo., Laramie, WY 82071. 70 p.

7. Hittle, G. F. 1983. Wyoming's leafy spurge program 1978-1982. Wyoming Dep. Agric., 2219 Carey Ave., Cheyenne, NW 82002. 39 p.

8. Malone, C. R. 1967. A rapid method for enumeration of viable seeds in soil. Weeds 15:381-382.

9. Selleck, G. W., R. T. Coupland, and C. Frankton. 1962. Leafy spurge in Saskatchewan. Ecol. Monogr. 32:1-29.

10. Wicks, G. A. and L. A. Derscheid. 1964. Leafy spurge seed maturation. Weeds 12:175-176.

Page 5 of 5 